\title{
WARTOŚCI RODZINNE W ZWIERCIADLE UKRAIŃSKICH PAREMII
}

\author{
PAULINA MURAWSKA \\ Uniwersytet im. Adama Mickiewicza w Poznaniu, Poznań — Polska \\ СІМЕЙНІ ЦІННОСТІ В ДЗЕРКАЛІ \\ УКРАЇНСЬКИХ ПАРЕМІЙ \\ ПАУЛІНА МУРАВСКА \\ Університет імені Адама Міцкевича, Познань — Польща
}

АНОТАЦІЯ. Стаття присвячена опису системи сімейних цінностей, що віддзеркалена в українських пареміях. Головною рисою, що відрізняє паремії від інших зразків усної народної творчості, є їхня невмираюча актуальність, тому добуті багатьма поколіннями й зафіксовані в пареміях знання про ціннісну орієнтацію сімейних стосунків заслуговують на різнобічне вивчення та увагу.

\section{FAMILY VALUES REFLECTED IN UKRAINIAN PROVERBS AND SAYINGS}

\author{
PAULINA MURAWSKA \\ Adam Mickiewicz University, Poznan — Poland
}

ABSRACT. The aim of this article is the reconstruction of family values in Ukrainian proverbs and sayings. The main feature that distinguishes proverbs and sayings from other samples of oral folklore is their relevance. Therefore knowledge about the value orientation in family relationships, gained by many generations and recorded in proverbs and sayings, deserves a comprehensive study and attention.

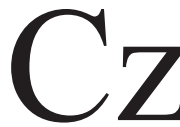

łowiek jest istotą społeczną" — to szeroko znane stwierdzenie Arystotelesa uznać można za podstawę wszelkich badań, skupiających się wokół socjalnych aspektów funkcjonowania jednostki ludzkiej. I choć może się to wydać z początku wątpliwe, to człowiek jest istotą społeczną już od chwili narodzin. To właśnie w momencie przyjścia na świat noworodek wydaje swój pierwszy krzyk, który, będąc reakcją fizjologiczną organizmu, jest też przecież komunikatem o jego fizycznej gotowości do życia. O wadze interakcji społecznej świadczy również to, że nie samodzielne operowanie rękami, siadanie, stawanie lub chodzenie, ale właśnie uśmiech staje się jedną z pierwszych nowych umiejętności kilkutygodniowego niemowlęcia.

Aby harmonijnie współistnieć z resztą społeczeństwa, człowiek musi poznać szereg zasad i norm. Pierwszą zaś grupą, z którą styka się nowonarodzony człowiek, w której ma szansę owych norm się nauczyć, jest rodzina. Великий тлумачний словник сучасної української мови ${ }^{1}$ definiuje pojęcie rodziny następującymi słowy: ,ciм'я - 1. Група людей, що складається з чоловіка, жінки, дітей та інших близьких родичів, які живуть разом; родина. 2. кого або з означ. перен. Група

${ }^{1}$ Великий тлумачний словник сучасної украӥнської мови, уклад. і голов. ред. В. Т. Бусел, Київ-Ірпінь 2005. 
людей, народів, націй, згуртованих дружбою, спільною діяльністю, спільними інтересами; родина". Rodzina jest więc w świetle tej definicji grupą opartą przede wszystkim na wspólnocie: wspólnocie miejsca zamieszkania, wspólnocie uczuć, wspólnocie działań i dążeń. Zbiorem norm, łączących grupę ludzi, stanowiących fundament ich wspólnej harmonijnej egzystencji, jest zaś kategoria wartości moralnych (por. ,мораль - 1. Система норм і принципів поведінки людей у ставленні один до одного та до суспільства; етика (у 2 знач.)"). Тo rodzina kształtuje drzemiący w nowym człowieku potencjał, ucząc go zachowań społecznie akceptowanych, przekazując mu wzorce wartości i norm moralnych, które będą mu odtąd towarzyszyły i do których będzie mógł się odwoływać, budując swoje relacje z innymi.

Moralność danej grupy społecznej jest, w szerszym kontekście, elementem jej kultury duchowej. Będąc zjawiskiem niematerialnym, kultura duchowa może być przekazywana między ludźmi, z pokolenia na pokolenie, dzięki jej werbalizacji. Jednym z najbardziej efektywnych sposobów werbalizacji zdobywanej przez pokolenia wiedzy, przekonań i światopoglądu są paremie ${ }^{2}$, czyli przysłowia i powiedzenia. W niniejszym artykule zaprezentowane zostaną rezultaty analizy lingwokulturologicznej 300 paremii ukraińskich, traktujących o wartościach moralnych w kontekście

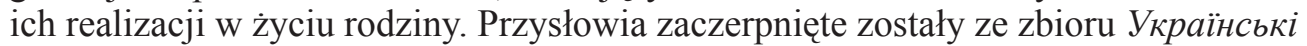
прислів'я та приказки , z rozdziału Родинне життя (Życie rodzinne — thum. aut.). W artykule przedstawione zostaną wyniki analizy ilościowej przysłów pod kątem gloryfikowanych w nich wartości moralnych, ważnych dla szczęśliwego funkcjonowania rodziny. Częściowo zostaną także opisane nakreślone w przysłowiach portrety moralne poszczególnych członków ukraińskiej rodziny.

Zgodnie z zawartą w przysłowiach mądrością, do najważniejszych dla życia rodzinnego wartości należy zaliczyć odpowiedzialność i rozwagę. To właśnie te cechy ukazane są jako pożądane aż w 107 na 300 przeanalizowanych przysłów. Rozsądne podejście do życia wyraża się na wielu płaszczyznach. W małżeństwie jest to wzajemna odpowiedzialność małżonków: Чоловік - голова в хаті, а жінка - капелюх на голові. Odpowiedzialność, rozwaga i mądrość to cechy, które w przysłowiach składaja się na portret dobrego męża: Батьки гладять дочку до віния, а чоловік - до кіния; Без чоловіка — то так, як без голови; За добрим мужем і воронка жонка, а за дурним і княгиня гине; Хоч чоловік, як ворона, а все жінці оборона.

Odpowiedzialność, rozumianą jako gospodarność i dbałość o wspólne dobro, powierzają przysłowia przede wszystkim żonie: Добра жінка з пучки муки пригорщу зробить; Розумна жона, як стоїть один міх муки, другий пшона, бодня сала на горі, стоги хліба на дворі. Gospodarność przejawia się w pracowitości i jako taka jest cechą pożądaną zarówno u kobiety: Без жінки - як без рук; Жіноча робота ніколи не лягає спати, jak i u mężczyzny: Сиди до сивої коси, а за ледащчо не йди; Не той гарний, щзо гарний, а той, щзо діло робить; Доброго молодия $і$ кров гріє, а ледачого і кожух не нагріє.

Istotne znaczenie ma także odpowiedzialność rodziców za dzieci. Dobrzy rodzice - to rodzice, którzy dbają o swoje dzieci, wychowują je: Не пой батько, щзо породив, а той, щзо до ума доводив; Не ті батьки, щзо на світ привели, а ті, щзо в люди вивели; Пізно женитися - дрібні сироти лишити. O roli ojca jako osoby, która w rodzinie odpowiada za utrzymanie dyscypliny, mówią takie przysłowia, jak: Ледача та дитина, котрої батько не вчив; Ледащо син — батькові гріх.

${ }^{2}$ K. Marjak, Номінант БОГяк компонент українських прислів '̈̈в, [в:] „, Wort — Text — Zeit”, Phraseologische Einheiten in traditionellen und neuen wissenschaftlichen Paradigmen, Greifswald 2009, s. 61.

${ }^{3}$ Українські прислів’я та приказки, уклад. С. В. Мишанич, М. М. Пазяк, Київ 1984. 
Dzieci z kolei przedstawiane są przede wszystkim jako nieodpowiedzialne i nieposłuszne: Дитині дай волю, то сам будеш у неволі; Не хочеш слухати тата, то послухаєи колись ката. Jednak najgorszą cechą dzieci jest ich niewdzięczność: Батько і мати виховують дванадиять дітей, а дванадиять дітей не можуть прогодувати на старість двох батьків; Скоріше один батько вигодує десять дітей, ніж десятеро дітей одного батька; Дітей годуй, а торби собі готуй.

W podobnym stopniu, co odpowiedzialność i rozwagę, pochwalają przysłowia szczerość i prostotę uczuć. Ta tematyczna grupa reprezentowana jest przez 85 paremii. Najbardziej wyraziste są obrazy ukazanej w nich mocy szczerej rodzicielskiej miłości: Батькова й материна молитва з дна моря рятує, а проклін - у калюжі топить; У дитини болить голова, а у матері - серие. To właśnie matka jest dla swych dzieci źródłem bezwarunkowej i bezgranicznej miłości: Любов матірня й на віддалі гріє; Мамина лайка - байка, а битва - молитва.

Portretowi kochającej matki przysłowia przeciwstawiają obraz fałszywej i złośliwej macochy: Мати б'є, то не болить, а мачуха як подивиться, то й на душі холоне; Горілка - не дівка, а мачуха - не мати; Мати голівку миє - пригладжує, а мачуха миє - прискубує. Na uwagę zasługuje wyrazistość przysłów, w których piętnowana jest postawa złej, okrutnej macochy: Горе мачусі, щ̧о пасинок сметани не їсть, бо він і сироватиі радий; Рідна мати - брехуха, то мачуха справедлива: як скаже: „Я тобі дам”, то вже дасть, а мати: „I щоб тебе, i бодай тебе”, а сама: „Ох, коли б, Господи, не сталось чогось дитині з моєї дурної речі!"; У вітчима чорт межи очима, а в мачухи - два.

Nieprzypadkowym zdaje się wykorzystany w przysłowiach o macosze motyw złego spojrzenia (Мати б' $\epsilon$, то не болить, а мачуха як подивиться, то й на душі холоне; У вітчима чорт межи очима, а в мачухи - два.). Jest on związany z zakorzenionym w wierzeniach pradawnych Słowian przekonaniem, że tzw. „złe” oko (a więc przepełnione złością i nienawiścią spojrzenie) może być przyczyną licznych chorób i nieszczęść ${ }^{4}$.

Macocha zasługuje na swój negatywny wizerunek przede wszystkim przez swoją nieprawdziwość - wszak to nie ona jest rzeczywistą matką. Kontynuacją podziału na „prawdziwą” i „nieprawdziwą” rodzinę jest zaklęty w przysłowia stereotypowy obraz teściów, których, zgodnie z tradycja, młodzi małżonkowie powinni traktować jak rodziców. Teściom przypisywane są takie przywary, jak kłamliwość i mściwość: Брехлива свекруха невістиі не вірить; Свекруха - уїдлива муха; Син б'є жінку, а свекор дубия дає.

Nieszczerość i fałsz to także sprzeniewierzenie się prawdziwym uczuciom. W ukraińskich paremiach jest ono przedstawiane jako przeszkoda na drodze do osiągnięcia rodzinnego szczęścia: Якщо візьмеш собі тую, що ї̈ не любиш, то свою долю навіки загубиш; Краще полин їсти, ніж з нелюбом за стіл сісти. Z drugiej strony, dość lekko i żartobliwie traktują ukraińskie przysłowia kwestię męskiej zdrady: То не біда, що з чужою жінкою жартував, аби дома ночував; I Гнат не винуват, і Килина не винна, тільки хата винувата, що впустила на ніч Гната; Тепер народ гіриий прошлоднього: прийшов звечора, а пішов вранці, уже й брешуть, щуо ночував. Warto przy tym zauważyć, że i mąż powinien wykazywać się w tych kwestiach wyrozumiałością w stosunku do żony: Не дай, Боже, коня лінивого, а чоловіка ревнивого; Ревнивий чоловік - щзо полохливий злодій.

Rzymski historyk i pisarz Sallustiusz stwierdził: Concordia res parvae crescunt, discordia vel maximae dilabantur (czyli, w polskim thumaczeniu, Zgoda buduje, nie-

${ }^{4}$ O. I. Потапенко, М. К. Дмитренко, Г. І. Потапенко та ін., Словник символів, Київ 1997. 
zgoda rujnuje)5. Ta uniwersalna prawda - Де згода панує, там і горе таниює znajduje swoje odbicie w 49 z przeanalizowanych ukraińskich przysłów. Zgoda jest więc fundamentem więzi, łączącej małżonków: Муж з жоною - що борошно з водою; Чоловік і жона - одно тіло, одно діло, один дух; Живуть собі, як голубів пара; Найкраша спілка — чоловік та жінка.

Gwarantem zgody i porządku w rodzinie są dzieci: У кого бджоли, у того й мед, у кого діти, у того й лад; Тут і я, тут і жінка моя, тут і мої діти, любо поглядіти. Zgoda panująca między rodzicami jest niezbędna dla tego, aby zapewnić dzieciom dobre wychowanie: Коли батько каже „,так”, а мати „сяк”, росте дитина як будяк.

Źródłem konfliktów może stać się z kolei zbyt duża różnica wieku między mężem a żoną: Де муж старий, а жінка молода, там рідко згода; Де чоловік старий, а жінка молода, там вогонь $і$ вода. Największym jednak nieszczęściem jest według przysłów kłótliwa żona: Дим, дощ, мороз i сварлива жона - то найбільше нещастя в хаті; Від вогню, води і злої жінки - Боже борони! Niestety, przekora i kłótliwość to powtarzający się element moralnego portretu kobiety: Жіночий язик гостріший від меча; Жінка нікому кроку не уступить, хіба що ї̈ миша налякає; Жіноча думка і вітер часто змінюються.

45 przysłów mówi o tym, że wartością zapewniającą szczęście rodzinie jest wzajemny szacunek jej członków. Jednym z przejawów szacunku jest przestrzeganie właściwej hierarchii, zgodnie z którą głową rodziny jest mąż: Голова сімейства - чоловік, а як піддасися жіниі, то не проси у Бога здоров'я; Зле там ся діє, де півень мовчить, а курка п'є; зле там і лихо, де жінка кричить, а чоловік тихо. I choć przysłowia niejednokrotnie ostrzegają przed poddawaniem się kobiecej władzy: Жінка доти люба, доки не візьме за чуба; Жінка його під ноги взяла, to jednak przypominają o tym, że będąc głową rodziny mąż także powinien szanować swoją żonę: Жінка чоловікові подруга, а не прислуга.

Zgodnie z ukraińską mądrością ludową hierarchia w rodzinie oznacza również podział na role - atrybutem moralnym mężczyzny jest to, co związane ze sferą rozumu, a kobiety to, co związane z emocjami: Чоловік у домі голова, а жінка - душа; Нема иввіту білішого над ожиноньку, нема друга милішого над дружиноньку.

Szacunkiem winny obdarzać swych rodziców dzieci: Шануй батька й неньку, то буде тобі скрізь гладенько; Діти батька не учать. Nieposłuszeństwo wobec rodziców może ściągać na dzieci złą dolę: Не послухаєш батька-матері, то навчить тебе лиха година; Хто батька-матір зневажає, той добра не знає. O szacunek ze strony dzieci powinni więc przez swoją stanowczość zabiegać i sami rodzice: Потурай малому, то як виросте, буде тебе на старість бити; Ліпше, щзоб дитина плакала тепер, як батьки опісля.

Pełna wzajemnego szacunku rodzina to miejsce, w którym każdy z jej członków szuka ciepła i schronienia. Dlatego też przysłowia ukraińskie piętnują stosowanie przemocy fizycznej i zastraszania, proponując jako metodę rozwiązywania problemów czułość i dobre słowo: Пий пиво, але не лий, люби жінку, але не бий; Не вчи дитину штурханцяяи, а хорошими слівцями; Учи дітей не страшкою, а ласкою.

W zebranym materiale aż 32 przysłowia zwracają uwagę na to, co stanowi ,wewnętrzne piękno" człowieka, które nierzadko nie idzie w parze z jego zewnętrzną urodą. Często bywa wręcz odwrotnie - uroda psuje moralność człowieka: Kpaca дере носа; Хоч не з красою, аби з головою. W związku z tym przysłowia przestrzegają mężczyzn przed ożenkiem z przykładającymi zbędną uwagę do wyglądu zewnętrznego pannami: Хто жениться на красі, той буде жити у біді.

\footnotetext{
${ }^{5}$ Cz. Jędraszko, Lacina na co dzień, Warszawa 1988, s. 51.
} 
Piękno zewnętrzne nie może być postrzegane jako wartość, gdyż nie jest trwałe: Краса до віния, а розум до кіния, a także nie idzie w parze z takimi wartościami moralnymi, jak mądrość, dobroć czy pracowitość: Бог до вроди розуму не прив'язав; Лице рум'яне, а серие кам'яне; Не в тім хороша, що чорноброва, а в тім, що діло робить; 3 красивого лиця води не пити, аби вміла їсти зварити; Хлопці б'ються чорт зна за що: хоч красива, та ледащо.

Ostatnimi z wyróżnionych przez nas wartości są wstrzemięźliwość i skromność. Tym cechom poświęconych jest zaledwie $5 \mathrm{z}$ poddanych analizie przysłów. Skromności wymaga się przede wszystkim od kobiet: Честь дівоче щастя береже. Jednak, jeśli wierzyć przysłowiom, wstrzemięźliwość, zwłaszcza w doborze i ilości wypowiadanych słów, to cechy rzadko u nich spotykane: Жінка мов торба: щзо в неї вложии, те й несе; Жінка хіба те утає, чого не знає; У парубка одна гадка, а в дівчини десять.

Podsumowując, do głównych wartości, na których opiera się, zgodnie z przysłowiami, ukraińska rodzina, zaliczyć należy takie cechy moralne, jak odpowiedzialność i rozwagę oraz szczerość i uczciwość. Obie grupy tematyczne są reprezentowane, odpowiednio, przez $36 \%$ i $28 \%$ zgromadzonych przysłów. Harmonijne funkcjonowanie rodziny opiera się też na panujących między jej członkami zgodzie (o której mówi $16 \%$ poddanych analizie paremii) i wzajemnym szacunku (promowanym przez 15\% przeanalizowanych przysłów), których filarami są zachowanie odpowiedniej hierarchii oraz odwoływanie się do argumentów słownych, a nie siłowych. Nieco ponad $10 \%$ zgromadzonego materiału podkreśla konieczność rozdzielenia piękna zewnętrznego, które jest jedynie fasada, od piękna wewnętrznego. W przypadku około $1 \%$ przysłów akcentowane są zaś takie wartości, jak skromność i wstrzemięźliwość. Warto przy tym zauważyć, że konkretne przysłowie może odnosić się do więcej niż jednej wartości, co znajduje swoje odbicie w zaprezentowanych w artykule danych liczbowych.

Przedstawiony $\mathrm{w}$ ukraińskich paremiach obraz idealnej rodziny jest sumą poszczególnych portretów ludzi o pięknym, czystym moralnie wnętrzu - męża i żony, ojca i matki, ich dzieci. I choć niektóre przysłowia przedstawiają dzieci w negatywnym świetle, to ich przeciwwagę stanowią paremie przekonujące o tym, że rodzice mogą w przyszłości oczekiwać od swoich dzieci tego, czego sami ich nauczą: Дитя, як дзеркало: все відбиває; Дитина - мов порожня посудина: що в неї ввіллєш, те й держить. Należy więc wierzyć, że system wartości, opanowywany przez człowieka w toku życia rodzinnego, będzie kształtował jego postawę moralną na resztę życia.

W tym kontekście pragmatyczne znaczenie przysłów jako skarbnicy wiedzy bliskiej człowiekowi, sprawdzonej przez pokolenia, jest niezaprzeczalne. To właśnie dlatego przysłowia nazywane bywają „,encyklopedią życia narodu”, „skarbnicą tradycji kulturowych”, „duchowym kodeksem narodu”, czy nawet „wizytówkami danej wspólnoty etno-kulturowej" zwykłą obrazowościa, przekazując bogatą treść w ciekawej i dobitnej, ale, tym nie mniej, prostej i przystępnej formie. Dlatego też warto sięgać po zaklęte w paremie wiedzę i doświadczenia nie tylko dla celów naukowych.

${ }^{6}$ 3. Г. Коцюба, До питання про пареміологічний парадокс, [в:] „Мовознавство” 2006, № 4, c. 41. 